\title{
Recent advances in understanding Epstein-Barr virus [version
}

\section{1; peer review: 4 approved]}

\author{
Brent A. Stanfield (D), Micah A. Luftig(iD)
}

Department of Molecular Genetics and Microbiology, Duke Center for Virology, Duke University Medical Center, Durham, NC, USA

V1 First published: 29 Mar 2017, 6(F1000 Faculty Rev):386

https://doi.org/10.12688/f1000research.10591.1

Latest published: 29 Mar 2017, 6(F1000 Faculty Rev):386

https://doi.org/10.12688/f1000research.10591.1

\section{Abstract}

Epstein-Barr virus (EBV) is a common human herpes virus known to infect the majority of the world population. Infection with EBV is often asymptomatic but can manifest in a range of pathologies from infectious mononucleosis to severe cancers of epithelial and lymphocytic origin. Indeed, in the past decade, EBV has been linked to nearly $10 \%$ of all gastric cancers. Furthermore, recent advances in high-throughput next-generation sequencing and the development of humanized mice, which effectively model EBV pathogenesis, have led to a wealth of knowledge pertaining to strain variation and hostpathogen interaction. This review highlights some recent advances in our understanding of EBV biology, focusing on new findings on the early events of infection, the role EBV plays in gastric cancer, new strain variation, and humanized mouse models of EBV infection.

\section{Keywords}

EBV, Herpesvirus, Herpes simplex virus, gastric cancer

\section{Open Peer Review}

Approval Status

$\begin{array}{lllll}1 & 2 & 3 & 4\end{array}$

\section{version 1}

29 Mar 2017

Faculty Reviews are review articles written by the prestigious Members of Faculty Opinions. The articles are commissioned and peer reviewed before publication to ensure that the final, published version is comprehensive and accessible. The reviewers who approved the final version are listed with their names and affiliations.

1. Christian Münz, Institute of Experimental Immunology, University of Zürich, Zurich, Switzerland

2. Alan K Chiang, Department of Paediatrics and Adolescent Medicine, The University of Hong Kong, Hong Kong, Hong Kong

3. Richard M. Longnecker, Northwestern University, Chicago, Chicago, USA

4. Bo Zhao, Brigham and Women's Hospital, Harvard Medical School, Boston, USA Any comments on the article can be found at the end of the article. 
Corresponding author: Micah A. Luftig (micah.luftig@duke.edu)

Competing interests: The authors declare that they have no competing interests.

Grant information: This work received funding support from the National Cancer Institute (grant R01CA140337) and the National Institute of Dental and Craniofacial Research (grant R01DE025994).

The funders had no role in study design, data collection and analysis, decision to publish, or preparation of the manuscript.

Copyright: $\odot 2017$ Stanfield BA and Luftig MA. This is an open access article distributed under the terms of the Creative Commons Attribution License, which permits unrestricted use, distribution, and reproduction in any medium, provided the original work is properly cited.

How to cite this article: Stanfield BA and Luftig MA. Recent advances in understanding Epstein-Barr virus [version 1; peer review: 4 approved] F1000Research 2017, 6(F1000 Faculty Rev):386 https://doi.org/10.12688/f1000research.10591.1

First published: 29 Mar 2017, 6(F1000 Faculty Rev):386 https://doi.org/10.12688/f1000research.10591.1 


\section{Introduction}

Epstein-Barr virus (EBV), also known as human herpes virus 4, is a gamma-herpes virus that infects the majority of the world's population. Initial infection with EBV is often asymptomatic but can also manifest as infectious mononucleosis. Following acute lytic replication in epithelial cells, EBV infects B cells where a distinct set of latency-associated genes and transcripts are expressed $^{1}$. EBV was first identified in 1964 from cultured tumor cells derived from a patient with Burkitt's lymphoma (BL) ${ }^{2}$. Early studies have demonstrated EBV's ability to transform resting human B cells into lymphoblastoid cell lines (LCLs), further supporting the oncogenic potential of this virus ${ }^{3,4}$. Since then, EBV infection has been associated with a number of different malignancies of both lymphoid and epithelial origin and accounts for $1.8 \%$ of all cancer-related deaths worldwide ${ }^{5}$.

In vivo, EBV infection begins in the oral mucosa. Replication in epithelial cells is typically lytic; however, latent infection of epithelial cells can result in nasopharyngeal carcinoma or gastric cancer (as discussed in more detail later). After replication in the epithelia, virus is primed for entry into B cells, where a transient growth program is thought to mimic a germinal center reaction, ultimately promoting maturation of the infected cell into the peripheral memory B-cell compartment. Advances in next-generation sequencing and the development of humanized mice have led to better ways to identify and understand the natural strain variation that occurs with EBV. New strain variations, particularly with mutations in latency-associated genes, have been identified in various malignancies. Harnessing these new humanized mice enables studies modeling latent infection and pathogenesis of host-restricted pathogens like HIV and EBV. This review will focus on the recent advances in EBV biology and primarily on understanding events in early B-cell infection, the role of EBV in gastric cancer, the breadth of EBV strain variation revealed by next-generation sequencing, and recent discoveries made using humanized mice.

\section{Early events}

Initial events of infection

EBV entry into epithelial cells occurs by direct fusion of the viral envelope with the cell plasma membrane; however, entry into $\mathrm{B}$ cells requires the virus to be endocytosed before membrane fusion to escape the endosome ${ }^{6,7}$. B-cell entry requires five viral glycoproteins: gp350/220 allows for attachment by binding to CD21, gp42 binds to major histocompatibility complex (MHC) class II to initiate entry ${ }^{8}$, and the core herpesvirus fusion machinery consisting of $\mathrm{gB}$ and the heterodimer $\mathrm{gH} / \mathrm{gL}$ (Figure 1) ${ }^{1}$. Interaction of gp350/220 with the cell surface molecule CD21 results in the alteration of major signaling pathways believed to prime the cell to stable latent EBV infection. In particular, specific transcriptional profiles are involved in the evasion of apoptosis and there is evidence that EBV/CD21 binding alters the expression of specific histone transcripts from clusters 1 and 2 (H2AFC, H2AFM, H2BF, H2BFG, H2BI, H3FA, H3FB, H3FL, H4FL, H4FK, H4FI, H4FK, H4F2, H1F3, and H1F4) (Figure 1) ${ }^{9}$.
Upon entry into B cells, the virion is endocytosed and is released into the cytoplasm following fusion of the virion membrane with endosomal membrane. This process releases the viral tegument proteins into the host cell. One such tegument protein, BNRF1, binds the cellular protein Daxx and disrupts the Daxx-ATRX complex ${ }^{10}$. This complex is known to suppress transcription through histone methylation ${ }^{11}$. Upon deposition into the nucleus, the viral DNA is associated with cellular histones ${ }^{12}$. Daxx-ATRX might normally support methylation of this new EBV chromatin to suppress transcription of viral genes. However, BNRF1 disruption of the Daxx-ATRX complex allows early viral latent gene expression (Figure 1) ${ }^{10}$.

Packaged, virally encoded RNA is also released upon fusion of the virion membrane with endosomal membrane. In particular, BZLF1 transcripts have been shown to be packaged into viral particles and are translated immediately upon release into the infected cell. These immediately translated proteins then function to transactivate viral promoters initiating the pre-latent phase of EBV infection. EBV also counters T-cell responses through the delivery of BNLF2a mRNA and non-coding EBV-encoded RNA transcripts that induce cellular cytokine synthesis ${ }^{13}$. EBV is known to encode at least 44 microRNAs (miRNAs). Though many of the miRNAs have no known function, it has recently been shown that these virally encoded miRNAs function in immune evasion by specifically suppressing the release of interleukin-12 (IL-12), disrupting $\mathrm{CD}^{+}{ }^{+} \mathrm{T}$-cell differentiation into type $1 \mathrm{~T}$ helper (Th1) cells, and reducing antigen presentation to $\mathrm{CD} 4^{+}$and $\mathrm{CD} 8^{+} \mathrm{T}$ cells. These miRNAs function by interfering with peptide processing, by directly targeting the TAP 2 subunit, and by disrupting antigen presentation on MHC-II and MHC-I molecules ${ }^{14,15}$.

\section{Pre-latent gene expression}

Pre-latent gene expression occurs immediately upon deposition of the viral genome into the nucleus of newly infected B cells. Promiscuous expression of both lytic and latent genes occurs at this time with the majority of infected B cells initially expressing EBV immediate-early genes ${ }^{16}$. Others have shown that BZLF1, the major transcriptional activator of lytic gene expression, is expressed as early as 1.5 hours post infection in the absence of protein expression, implicating BZLF1 as an immediate-early gene being expressed immediately following B-cell infection ${ }^{17}$. This initial burst of lytic gene expression could be essential to the production of progeny virus competent for infecting new B cells ${ }^{18}$, or immediate expression of lytic genes could be essential for the survival of latently infected B cells through inactivation of $\mathrm{p} 53^{19}$. However, it is important to note that during this pre-latent phase, genes essential for DNA replication and structural proteins of the virion are not readily detectable ${ }^{16}$.

EBV encodes two bcl-2 proteins: BHRF1 and BALF1. Viral mutants lacking both bcl-2 proteins are unable to initiate proliferation and die from immediate apoptosis. Peak expression of these transcripts is detected at 24 hours post infection, implicating BHRF1 and BALF1 in the initial events prior to cell proliferation ${ }^{20}$. Also, it has recently been shown that BHRF1 is constitutively expressed 


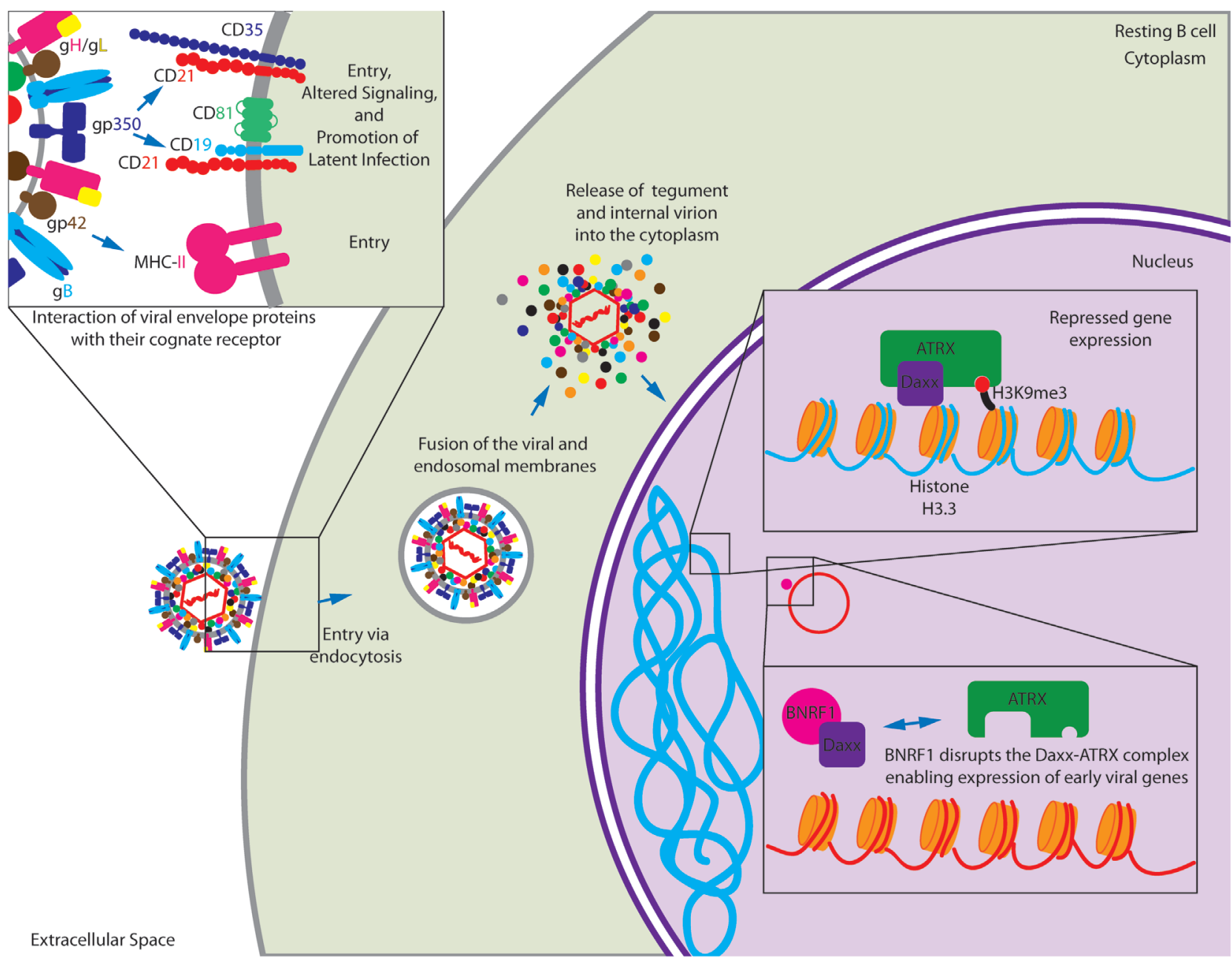

Figure 1. Initial events of Epstein-Barr virus (EBV) infection. The EBV membrane glycoprotein gp42 binds to its cell surface receptor major histocompatibility complex class II (MHC-II) to initiate entry into the cell. Also, gp350/220 binds to its cell surface receptor CD21 for entry. Interaction with CD21 initiates signaling cascades that prime resting B cells for persistent latent infection. Following endocytosis, the virion and packaged tegument proteins are released into the cytoplasm following fusion of the virion membrane with endosomal membrane. In particular, BNRF1 disrupts the Daxx/ATRX repressor complex to facilitate viral gene expression.

as a latent protein in BamHI W promoter (Wp)-restricted BL cell lines and LCLs ${ }^{21}$. These findings implicate BHRF1 and BALF1 proteins as playing an important role in the evasion of apoptosis during latency; however, virally encoded miRNAs also cluster at the BHRF1 locus. Following induction of viral replication in latency I restricted Akata cells, these miRNAs are detectable at 24 hours post stimulation and have been shown to drive proliferation and aid in the evasion of apoptosis ${ }^{22-24}$.

\section{Hyper-proliferation}

Following the pre-latent phase, the initial Epstein-Barr nuclear antigen (EBNA) latency promoter, $\mathrm{Wp}$, is active promoting expression of EBNA-LP and EBNA2. Subsequently, these proteins transactivate the viral $C$ promoter, $\mathrm{Cp}$, to initiate expression of the EBNA3s and EBNA1 along with their own transcripts to high levels. This EBNA-only gene expression state is associated with a period of rapid proliferation with the first three or four divisions occurring once every 8 to 12 hours ${ }^{25}$. This period lasting approximately the first 2 weeks following resting B-cell infection is termed latency $\mathrm{IIb}^{26,27}$. At this time, the virus expresses all of the EBNA proteins and minimally expresses latent membrane proteins (LMPs) 1, 2A, and $2 \mathrm{~B}^{26}$. LMP1 is expressed as early as 2 days post infection; however, during this period, inhibition of early nuclear factor-kappa $B$ (NFKB) activation does not affect transformation, supporting the distinction of this latency phase from the LCL state, which requires LMP1-mediated NFKB activity for survival ${ }^{26}$.

As a consequence of this rapid proliferation, EBV-infected $B$ cells are susceptible to growth arrest induced by hyperproliferation-associated DNA damage response ${ }^{26,28}$. Cells then transition from a period of rapid proliferation and high Myc activity to the steady-state proliferation (about 24 hours per cycle) observed in LCLs with lower Myc and high NFKB activity ${ }^{26,29,30}$. The high Myc/low NFאB state that occurs during latency IIb 
might play a role in immune evasion as elevated Myc and low $\mathrm{NF \kappa B}$ as observed in BL have been implicated in downregulation of MHC class I and II (MHC-I and MHC-II) and avoidance of T-cell recognition and killing 29,30 .

\section{Epstein-Barr virus infection in gastric cancer}

Viral entry into epithelial cells is primarily mediated by three CD21-independent mechanisms. First, EBV can enter into epithelial cells by close membrane-to-membrane contact of EBV-infected lymphocytes to uninfected epithelial cells. Second, cell-free virus can enter polarized epithelial cells through their basolateral membranes which is mediated in part by interaction between BMRF2 and beta1 and alpha5beta1 integrins. The third mechanism is by lateral spread through the epithelium from infected to uninfected epithelial cells ${ }^{31}$. EBV-associated gastric carcinomas (EBVaGCs) are epithelial in origin and make up approximately $9 \%$ of all gastric carcinomas worldwide ${ }^{32}$. EBVaGCs characteristically acquire mutations within the cellular PIK3CA gene and display extreme cellular DNA hyper-methylation. Specifically, mutations in $P I K 3 C A$ identified in intestinal-type gastric cancers were associated with an increased tumor incidence in the lower third of the stomach compared with those without ${ }^{33}$. Also, PIK3CA mutations in diffuse-type gastric cancer were associated with an increased tumor incidence in the upper third of the stomach and an increased association with hematogenous metastasis. Tumors identified with PIK3CA mutation in the middle third of the stomach had an increased association with EBV infection and increased peritoneal recurrence; however, PIK3CA mutations did not demonstrate a significant effect on patient outcomes.

EBVaGCs are also known to have increased expression of JAK2, programmed death ligand 1 (PD-L1), and PD-L2 ${ }^{34}$. PD-L1 is known to interact with programmed death receptor 1 found on the surface of $\mathrm{T}$ cells. This interaction causes the inhibition of T-cell proliferation, cytokine secretion, and cytotoxic activity (reviewed in 35). Also, EBVaGCs have been shown to express BNLF2a, which functions in immune evasion by inhibiting the transporter associated with antigen-processing transport of antigenic peptides. Though this transcript is typically associated with lytic replication, in gastric cancers it is expressed latently and has the potential to protect the infected cell from immunosurveillance ${ }^{36}$. Despite the immunologically evasive nature of EBVaGC, patients with diagnosed EBVaGC had longer survival post diagnosis as opposed to EBV-negative gastric carcinoma ${ }^{37}$.

Infection of an EBV-negative GC cell line (AGS) with Akata EBV results in robust expression of virally encoded BART miRNAs with minimal protein expression ${ }^{38}$. Importantly, these infected AGS cells displayed a more transformed phenotype than their uninfected counterparts. The prototypical transforming EBV strain, B95-8, readily infects and immortalizes human B cells. However, this virus is deleted for most of the BART miRNAs, and infection of $\mathrm{B}$ cells with viral variants encoding these miRNAs results in minimal BART expression ${ }^{39,40}$. This tissue-specific BART expression suggests that these miRNAs are likely to play a significant role in the transformed growth properties of EBVaGC.
Recently, it has been shown that CRISPR/Cas9-mediated cleavage for bacterial artificial chromosome (BAC) insertion into EBV episomal DNA in gastric carcinoma (GC) cell lines has facilitated the cloning of these viral genomes with unprecedented efficiency ${ }^{41}$. Subsequent infection of epithelial cells with the BAC clone reconstituted viruses induced resistance to oncogene-induced cell death, providing important clues concerning EBV-mediated epithelial carcinogenesis. Establishing this new state-of-the-art technique will enable future investigation into new strain variations and their relationship with $\mathrm{EBV}$-associated disease.

\section{Epstein-Barr virus strain variation}

Recent advances in next-generation whole genome sequencing (NGS) have changed the landscape surrounding the analysis of EBV-type differences. Historically, the major distinction in EBV strains has been the delineation of type 1/type 2. Currently, the largest distinguishing factors between EBV type 1 and type 2 rely on differences observed in the EBNA2 and EBNA3A,EBNA3B, and $E B N A 3 C$ genes. Indeed, it has been shown that a single amino acid change in the transactivation domain of EBV-2 EBNA2 (S442D) can drastically alter EBV-2 B-cell transformation efficacy similar to that observed with EBV-1 and increase induction of LMP1 expression with a higher affinity for the LMP1 promoter $^{42}$. However, a number of other factors may contribute to the underlying strain variation, including immunological pressures, skewed cell tropism, and geographic isolation ${ }^{43}$. Indeed, a recently described strain of EBV derived from a nasopharyngeal carcinoma case, M81, displays high epithelial tropism and also contains a polymorphism in the promoter of the lytic transactivator BZLF1 leading to elevated lytic replication ${ }^{44}$.

It has been proposed that the prevalence of MHC haplotypes within specific geographic regions induces immunological pressures that can contribute to strain variation within immunologically dominant epitopes of particularly immunogenic proteins ${ }^{45}$. However, recent sequence analyses demonstrate that the large numbers of non-synonymous mutations observed in the EBNA3 proteins are outside of known cytotoxic T-cell epitopes. More work is needed to identify alternative cytotoxic T lymphocyte (CTL) epitopes within the EBNA3s to explain this variation, or alternatively another selective pressure could be driving this variation perhaps regarding EBNA3 function ${ }^{43}$. For example, a recent study found that EBNA3B, an immunodominant latency protein, actually serves as a tumor suppressor and can be found deleted in EBV strains associated with diffuse large B-cell lymphomas (DLBCLs) $)^{46}$.

Recently, a provocative study implicated EBV-2 as having unique cell tropism skewing toward $\mathrm{CD} 8^{+} \mathrm{T}$ cells ${ }^{47}$. EBV has also been commonly detected in non-B cells in the blood of patients with EBV-positive lymphoproliferative disorder (LPD), including patients with HIV, post-transplant, anaplastic anemia, chronic active EBV (CA-EBV), and others ${ }^{48,49}$. While CA-EBV patients often had EBV+ T cells in the blood, other EBV+ LPD patients contained EBV in monocytes as well as non- $\mathrm{B}$, non- $\mathrm{T}$, non-monocyte cell types based on surface staining ${ }^{49}$. Although this population is 
certainly skewed from the norm with elevated viral loads and altered EBV immune responses, these findings suggest that EBV infection of $\mathrm{T}$ cells may be clinically relevant in some instances. Indeed, the detection of EBV in natural killer (NK)/T lymphomas ${ }^{50}$ and a high percentage of $\mathrm{T}$ cells in EBV-associated hemophagocytic lymphohistiocytosis (HLH $)^{51}$ suggest that lack of control of EBV infection might be associated with a broadening of cellular tropism. Interestingly, cases of CA-EBV are most commonly reported as being of $\mathrm{T}$ and NK cell origin in $\mathrm{Asia}^{52}$ and almost entirely B-cell origin in the United States ${ }^{53}$. Information gained through NGS studies coupled with further virus-host interaction work in vitro and clinical observation will lead to a greater understanding of how different EBV strains might achieve these drastic differences in cellular tropism and maintenance of latency in various cell types.

\section{Humanized mouse models of Epstein-Barr virus infection}

EBV infection had been restricted to in vitro systems until the breakthrough of the scid-hu PBL mouse. Scid-hu PBL mice are based on the C.B-17 severe combined immunodeficient (SCID) mouse, which lack both $\mathrm{B}$ and $\mathrm{T}$ cells ${ }^{54}$. These mice are injected with human peripheral blood mononuclear cells and, after infection with EBV, effectively model the LPD observed in immunocompromised humans (reviewed in 55). However, these mice have several drawbacks, including frequently observed graft-versus-host disease caused by the human $\mathrm{T}$ cells attacking mouse tissue, the transient nature of the engrafted human immune system, and a relatively low level of engraftment. Most importantly, these mice are unable to mount adaptive immune responses with their engrafted immune systems.

In order to overcome the obstacles of the scid-hu PBL mouse model, a new suite of humanized mice was generated by transplantation of non-obese diabetic/SCID (NOD/SCID) animals with hematopoietic stem cells. These NOD/SCID mice have a complete null mutation of the common IL-2 cytokine receptor gamma chain-NOD/LtSz-scid/IL-2 receptor gamma null (NSG), NOD/ Shi-scid/IL-2 receptor gamma null (NOG)—and, once transplanted, display a humanized immune system that persists for more than 24 weeks post transplant (reviewed in 56). In this model, the $\mathrm{CD} 34^{+}$hematopoietic stem cells are able to differentiate into various mature blood cells, including myelomonocytes, dendritic cells, erythrocytes, platelets, and lymphocytes. B cells undergo normal class switching, produce normal immunoglobulins, and even infiltrate into mucosal tissues in these mice. However, it is important to note that circulating $\mathrm{IgG}$ is approximately 1,000 times lower than that observed in immunocompetent humans and that infiltration into mucosal tissues has been demonstrated to be severely attenuated. Differentiated $\mathrm{T}$ cells display human MHC-I/HLA-restricted cytotoxic functions: a vast improvement over scid-hu PBL mice ${ }^{57}$. The introduction of the human HLA $A 2$ allele into NSG mice transplanted with $\mathrm{CD} 34^{+}$hematopoietic stem cells (NSG-HLA-A2) resulted in mice capable of reproducing adaptive immune responses known to occur after EBV infection of HLA A2-expressing individuals ${ }^{58}$. These NSG-HLA-A2 mice have been used to demonstrate the essential contribution of NK cells in controlling EBV infection with $\mathrm{NK}$ depletion resulting in the development of disseminated $\mathrm{EBV}^{+}$lymphomas ${ }^{59}$. Further still, the BLT-NOD mice were developed by transplantation of autologous human hematopoietic fetal liver $\mathrm{CD}_{3} 4^{+}$cells into NOD/SCID mice previously implanted with human fetal thymic and liver tissues. This resulted in long-term, systemic human T-cell homeostasis capable of mounting anti-EBV MHC-I and MHC-II restricted adaptive immune responses ${ }^{60}$. Given the vast improvements in small animal models of EBV infection, we now have the tools to study post-transplant LPD in the context of a human immune system, adaptive immune responses to EBV infection, and an experimental model to understand the in vivo effects of strain variation and other important biological questions.

Humanized mice have been shown to demonstrate the cardinal features of EBV-associated diseases developing B-cell LPD, EBV-associated HLH, and erosive arthritis resembling rheumatoid arthritis (RA). NOG humanized mice injected with $10^{3} 50 \%$ transforming dose (TD50) of EBV develop B-cell LPD. This LPD models the histological and viral gene expression signature observed in immunocompromised patients. Lower dose infection of less than or equal to 10 TD50 in NOG humanized mice resulted in a persistent asymptomatic infection with adaptive $\mathrm{CD}^{+}$ T-cell responses and virus-specific IgM detectable in the serum of infected animals ${ }^{61}$. Infection of NOG humanized mice has also been shown to result in the cardinal features of HLH with infected animals developing hemophagocytosis, erythrocytopenia, thrombocytopenia, hypercytokinemia, histiocyte proliferation and infiltration of activated $\mathrm{CD} 8^{+} \mathrm{T}$ cells into the spleen ${ }^{62}$. EBV has been implicated in the pathogenic manifestation of RA. Patients with this disorder demonstrate elevated EBV reactive antibody titers and impaired lymphocyte responses to EBV, and EBV has been identified in the synovial fluid of patients with RA, indirectly implicating EBV in RA pathogenesis ${ }^{63-65}$. Modeling this pathological phenotype, humanized NOG mice infected with EBV develop an erosive arthritis. However, these findings are purely morphological and require in-depth molecular characterization to further validate this model ${ }^{66}$. A detailed description of recent publications involving the use of humanized mice in EBV research can be found in Table 1.

\section{Concluding remarks}

The recent advances described in this review address many of the key questions facing the EBV field today. With the advent of NGS and the development of humanized mice to better model EBV disease in vivo, we now have the tools to better understand the effects of strain variation on the development of EBVassociated diseases. Future research will benefit from further refinement of the humanized mouse models to better model the full spectrum of the human immune response to EBV infection with the aim of developing effective EBV-specific prophylactics and therapeutics. Further studies of the early period after B-cell infection and its contribution to tumorigenesis and immune evasion will be important to study in the humanized mouse. Finally, 
Table 1. Epstein-Barr virus humanized mouse studies.

\begin{tabular}{|c|c|c|c|c|}
\hline Mouse & $\begin{array}{l}\text { Epstein-Barr virus } \\
\text { strain }\end{array}$ & Year & Findings & References \\
\hline $\begin{array}{l}\text { NSG+CD34-depleted human } \\
\text { cord blood mononuclear cells }\end{array}$ & $\begin{array}{l}\text { M81 BAC and p2089 } \\
\text { B95-8 LMP1-KO }\end{array}$ & 2016 & $\begin{array}{l}\text { Blocking PD-1/CTLA-4 inhibits Epstein-Barr virus } \\
\text { (EBV)-induced lymphoma growth. }\end{array}$ & 67 \\
\hline $\begin{array}{l}\text { NSG+purified CD34-positive } \\
\text { cells from individual fetal liver } \\
\text { samples }\end{array}$ & GFP-EBV B95-8 WT & 2016 & $\begin{array}{l}\text { Leukocytes lacking cognate HLA ligands interfere with } \\
\mathrm{KIR}^{+} \text {natural killer (NK) recognition of HLA- tumors but } \\
\text { improve NK-mediated control of EBV infection. }\end{array}$ & 68 \\
\hline $\begin{array}{l}\text { NSG-A2tg (expressing } \\
\text { HLA-A2)+purified CD34-positive } \\
\text { cells from two fetal liver samples }\end{array}$ & $\begin{array}{l}\text { M81BAC, } \\
\text { M81BAC } \triangle \mathrm{C} 1, \\
\text { M81BAC } \Delta \mathrm{C} 2, \\
\text { M81BAC } \triangle \mathrm{C} 1 \mathrm{C} 2, \\
\text { M81BAC } \Delta \mathrm{b} 2 \text {, and } \\
\text { M81BAC } \Delta \text { All }\end{array}$ & 2015 & $\begin{array}{l}\text { BART microRNAs repress tumorigenesis in vivo and } \\
\text { likely facilitate long-term persistence in the infected } \\
\text { host. }\end{array}$ & 69 \\
\hline $\begin{array}{l}\text { Rag2 }^{-/-} \gamma^{-/-} \text {double } \\
\text { knockout+human hematopoietic } \\
\text { stem cells injected into the liver }\end{array}$ & $\begin{array}{l}\text { 293EBV }+ \text { and } \\
\text { 293EBVdelta } \\
\text { (BPLF1-KO) }\end{array}$ & 2015 & BPLF1 contributes to EBV oncogenicity. & 70 \\
\hline $\begin{array}{l}\text { NSG+purified human } \\
\text { cord blood CD34-positive } \\
\text { hematopoietic stem cells } \\
\text { injected into the liver }\end{array}$ & B95-8 & 2015 & $\begin{array}{l}\text { EBV-associated Hodgkin's lymphoma develops } \\
\text { exclusively in mice with activated T-cell conditions and } \\
\text { EBV-associated non-Hodgkin's lymphoma develops } \\
\text { in mice with a largely suppressed T-cell condition } \\
\text { predominantly characterized with an abundance of } \\
\text { immature B cells. }\end{array}$ & 71 \\
\hline $\begin{array}{l}\text { NSG-A2tg + purified human } \\
\text { cord blood CD34-positive } \\
\text { hematopoietic stem cells } \\
\text { injected into the liver }\end{array}$ & $\begin{array}{l}\text { B95-8 BAC, EBER1 } \\
\text { or EBER2 deletion } \\
\text { mutants, and } \\
\text { revertant viruses }\end{array}$ & 2015 & $\begin{array}{l}\text { Wild-type and EBER-deleted mutant viruses } \\
\text { demonstrate equal ability to persist in vivo. }\end{array}$ & 72 \\
\hline $\begin{array}{l}\text { NSG+purified human fetal liver } \\
\text { CD34-positive hematopoietic } \\
\text { stem cells injected into the liver }\end{array}$ & B95-8 GFP+ & 2015 & $\begin{array}{l}\text { The human SAP-dependent 2B4 receptor is required for } \\
\text { CD8 } \mathrm{T} \text { cell-mediated control of EBV infection. }\end{array}$ & 73 \\
\hline $\begin{array}{l}\text { NSG+purified CD34-positive } \\
\text { cells from individual fetal liver } \\
\text { samples and fetal thymus from } \\
\text { the same donor }\end{array}$ & $\begin{array}{l}\text { p2089 B95-8 BAC } \\
\text { and p2089 B95-8 } \\
\text { BAC LMP1-KO }\end{array}$ & 2015 & $\begin{array}{l}\text { LMP1 is not essential for EBV-induced lymphomas } \\
\text { in vivo, and T cells supply signals that substitute for } \\
\text { LMP1 in EBV-positive B-cell lymphomagenesis. }\end{array}$ & 74 \\
\hline $\begin{array}{l}\text { NSG-A2tg + purified human } \\
\text { cord blood CD34-positive } \\
\text { hematopoietic stem cells } \\
\text { injected into the liver }\end{array}$ & $\begin{array}{l}\text { Wild-type B95-8 and } \\
\text { BZLF1 knockout }\end{array}$ & 2014 & $\begin{array}{l}\text { T cells specific for the lytic EBV antigen BMLF1 can } \\
\text { effectively control lytically replicating } \mathrm{EBV}^{+} \mathrm{B} \text { cells } \\
\text { in vivo. }\end{array}$ & 75 \\
\hline 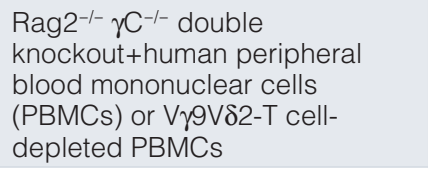 & $\begin{array}{l}\text { B95-8 and } \\
\text { B95.8EBfaV-GFP }\end{array}$ & 2014 & V $\gamma 9 \mathrm{~V} \delta 2-\mathrm{T}$ cells contribute to EBV immunity. & 76 \\
\hline $\begin{array}{l}\text { NSG+purified CD34-positive } \\
\text { human cord blood mononuclear } \\
\text { cells }\end{array}$ & B95-8 & 2014 & $\begin{array}{l}\text { CD4+ } T \text { cells are necessary for the generation/ } \\
\text { maintenance of cells with latency I/lla phenotype in } \\
\text { humanized mice and contribute to this process through } \\
\text { expression of CD40L. }\end{array}$ & 77 \\
\hline
\end{tabular}

the role of EBV in epithelial malignancies and other diseases outside of the B-cell compartment is ripe for study in this postgenomic era of EBV biology.

\section{Competing interests}

The authors declare that they have no competing interests.

\section{Grant information}

This work received funding support from the National Cancer Institute (grant R01CA140337) and the National Institute of Dental and Craniofacial Research (grant R01DE025994).

The funders had no role in study design, data collection and analysis, decision to publish, or preparation of the manuscript. 
1. Knipe DM, Howley PM: Fields virology. 6th ed. Philadelphia, PA: Wolters Kluwer/ Lippincott Williams \& Wilkins Health. 2013; 2.

Reference Source

2. Epstein MA, Achong BG, Barr YM: Virus Particles In Cultured Lymphoblasts From Burkitt's Lymphoma. Lancet. 1964; 1(7335): 702-3. PubMed Abstract | Publisher Full Text

3. Henle W, Diehl V, Kohn G, et al:: Herpes-type virus and chromosome marker in normal leukocytes after growth with irradiated Burkitt cells. Science. 1967; 157(3792): 1064-5

PubMed Abstract | Publisher Full Text

4. Pope JH, Horne MK, Scott W: Transformation of foetal human keukocytes in vitro by filtrates of a human leukaemic cell line containing herpes-like virus. Int J Cancer. 1968; 3(6): 857-66.

PubMed Abstract | Publisher Full Text

5. F Khan G, Hashim MJ: Global burden of deaths from Epstein-Barr virus attributable malignancies 1990-2010. Infect Agent Cancer. 2014; 9(1): 38. PubMed Abstract | Publisher Full Text | Free Full Text | F1000 Recommendation

6. Miller N, Hutt-Fletcher LM: Epstein-Barr virus enters B cells and epithelial cells by different routes. J Virol. 1992; 66(6): 3409-14.

PubMed Abstract | Free Full Text

7. Nemerow GR, Cooper NR: Early events in the infection of human B lymphocytes by Epstein-Barr virus: the internalization process. Virology. 1984; 132(1): 186-98.

PubMed Abstract

8. Mullen MM, Haan KM, Longnecker R, et al.: Structure of the Epstein-Barr virus gp42 protein bound to the MHC class II receptor HLA-DR1. Mol Cell. 2002; 9(2): 375-85

PubMed Abstract | Publisher Full Text

9. F Arredouani MS, Bhasin MK, Sage DR, et al:: Analysis of host gene expression changes reveals distinct roles for the cytoplasmic domain of the Epstein-Barr virus receptor/CD21 in B-cell maturation, activation, and initiation of virus infection. $J$ Virol. 2014; 88(10): 5559-77.

PubMed Abstract | Publisher Full Text | Free Full Text | F1000 Recommendation

10. Tsai K, Thikmyanova N, Wojcechowskyj JA, et al.: EBV tegument protein BNRF1 disrupts DAXX-ATRX to activate viral early gene transcription. PLOS Pathog. 2011; 7(11): e1002376.

PubMed Abstract | Publisher Full Text | Free Full Text

11. Xue $Y$, Gibbons R, Yan Z, et al:: The ATRX syndrome protein forms a chromatinremodeling complex with Daxx and localizes in promyelocytic leukemia nuclear bodies. Proc Natl Acad Sci U S A. 2003; 100(19): 10635-40. PubMed Abstract | Publisher Full Text | Free Full Text

12. Shaw JE, Levinger LF, Carter CW Jr: Nucleosomal structure of Epstein-Barr virus DNA in transformed cell lines. J Virol. 1979; 29(2): 657-65. PubMed Abstract | Free Full Text

13. F Jochum $S$, Ruiss R, Moosmann A, et al:: RNAs in Epstein-Barr virions control early steps of infection. Proc Natl Acad Sci U S A. 2012; 109(21): E1396-404.

PubMed Abstract | Publisher Full Text | Free Full Text | F1000 Recommendation

14. F Albanese M, Tagawa $\mathrm{T}$, Bouvet $\mathrm{M}$, et al.: Epstein-Barr virus microRNAs reduce immune surveillance by virus-specific $\mathrm{CD}^{+} \mathrm{T}$ cells. Proc Natl Acad $\mathrm{Sci}$ U S A. 2016; 113(42): E6467-E6475.

PubMed Abstract | Publisher Full Text | Free Full Text | F1000 Recommendation

15. F Tagawa $\mathrm{T}$, Albanese $\mathrm{M}$, Bouvet $\mathrm{M}$, et al.: Epstein-Barr viral miRNAs inhibit antiviral $\mathrm{CD}^{+}{ }^{+} \mathrm{T}$ cell responses targeting IL-12 and peptide processing. $J$ Exp Med. 2016; 213(10): 2065-80.

PubMed Abstract | Publisher Full Text | Free Full Text | F1000 Recommendation

16. F Kalla M, Schmeinck A, Bergbauer M, et al:: AP-1 homolog BZLF1 of EpsteinBarr virus has two essential functions dependent on the epigenetic state of the viral genome. Proc Natl Acad Sci U S A. 2010; 107(2): 850-5. PubMed Abstract | Publisher Full Text | Free Full Text | F1000 Recommendation

17. Wen W, Iwakiri D, Yamamoto K, et al:: Epstein-Barr virus BZLF1 gene, a switch from latency to lytic infection, is expressed as an immediate-early gene after primary infection of B lymphocytes. J Virol. 2007; 81(2): 1037-42. PubMed Abstract | Publisher Full Text | Free Full Text

18. Halder S, Murakami M, Verma SC, et al:: Early events associated with infection of Epstein-Barr virus infection of primary B-cells. PLoS One. 2009; 4(9): e7214 PubMed Abstract | Publisher Full Text | Free Full Text

19. Zhang Q, Gutsch D, Kenney S: Functional and physical interaction between p53 and BZLF1: implications for Epstein-Barr virus latency. Mol Cell Biol. 1994; 14(3): 1929-38.

PubMed Abstract | Publisher Full Text | Free Full Text

20. Altmann M, Hammerschmidt W: Epstein-Barr virus provides a new paradigm: a requirement for the immediate inhibition of apoptosis. PLOS Biol. 2005; 3(12): 0404

PubMed Abstract | Publisher Full Text | Free Full Text

21. Kelly GL, Long HM, Stylianou J, et al:: An Epstein-Barr virus anti-apoptotic protein constitutively expressed in transformed cells and implicated in burkitt lymphomagenesis: the Wp/BHRF1 link. PLoS Pathog. 2009; 5(3): e1000341. PubMed Abstract | Publisher Full Text | Free Full Text

22. Feederle $\mathrm{R}$, Linnstaedt $\mathrm{SD}$, Bannert $\mathrm{H}$, et al.: A viral microRNA cluster strongly potentiates the transforming properties of a human herpesvirus. PLoS Pathog. 2011; 7(2): e1001294.

PubMed Abstract | Publisher Full Text | Free Full Text

23. Seto E, Moosmann A, Grömminge S, et al:: Micro RNAs of Epstein-Barr virus promote cell cycle progression and prevent apoptosis of primary human $B$ cells. PLoS Pathog. 2010; 6(8): e1001063. PubMed Abstract | Publisher Full Text | Free Full Text

24. Xing L, Kieff E: Epstein-Barr virus BHRF1 micro- and stable RNAs during latency III and after induction of replication. J Virol. 2007; 81(18): 9967-75. PubMed Abstract | Publisher Full Text | Free Full Text

25. Nikitin PA, Yan CM, Forte E, et al:: An ATM/Chk2-mediated DNA damageresponsive signaling pathway suppresses Epstein-Barr virus transformation of primary human B cells. Cell Host Microbe. 2010; 8(6): 510-22. PubMed Abstract | Publisher Full Text | Free Full Text

26. Price AM, Tourigny JP, Forte E, et al:: Analysis of Epstein-Barr virus-regulated host gene expression changes through primary B-cell outgrowth reveals delayed kinetics of latent membrane protein 1-mediated NF-KB activation. J Virol. 2012; 86(20): 11096-106.

PubMed Abstract | Publisher Full Text | Free Full Text

27. Klein E, Nagy N, Rasul AE: EBV genome carrying $B$ lymphocytes that express the nuclear protein EBNA-2 but not LMP-1: Type llb latency. Oncoimmunology. 2013; 2(2): e23035.

PubMed Abstract | Publisher Full Text | Free Full Text

28. Nikitin PA, Price AM, McFadden $\mathrm{K}$, et al.: Mitogen-induced B-cell proliferation activates Chk2-dependent G1/S cell cycle arrest. PLoS One. 2014; 9(1): e87299. PubMed Abstract | Publisher Full Text | Free Full Text

29. F God JM, Cameron C, Figueroa J, et al:: Elevation of c-MYC disrupts HLA class II-mediated immune recognition of human B cell tumors. J Immunol. 2015; 194(4): 1434-45.

PubMed Abstract | Publisher Full Text | Free Full Text | F1000 Recommendation

30. Staege MS, Lee SP, Frisan T, et al.: MYC overexpression imposes a nonimmunogenic phenotype on Epstein-Barr virus-infected $B$ cells. Proc Natl Acad Sci U S A. 2002; 99(7): 4550-5. PubMed Abstract | Publisher Full Text | Free Full Text

31. F Tugizov SM, Berline JW, Palefsky JM: Epstein-Barr virus infection of polarized tongue and nasopharyngeal epithelial cells. Nat Med. 2003; 9(3): 307-14.

PubMed Abstract | Publisher Full Text | F1000 Recommendation

32. Shibata D, Weiss LM: Epstein-Barr virus-associated gastric adenocarcinoma. Am J Pathol. 1992; 140(4): 769-74.

PubMed Abstract | Free Full Tex

33. F Fang WT, Huang KH, Lan YT, et al:: Mutations in PI3K/AKT pathway genes and amplifications of PIK3CA are associated with patterns of recurrence in gastric cancers. Oncotarget. 2016; 7(5): 6201-20. PubMed Abstract | Publisher Full Text | Free Full Text | F1000 Recommendation

34. F Cancer Genome Atlas Research Network: Comprehensive molecular characterization of gastric adenocarcinoma. Nature. 2014; 513(7517): 202-9. PubMed Abstract | Publisher Full Text | Free Full Text | F1000 Recommendation

35. Blank C, Mackensen A: Contribution of the PD-L1/PD-1 pathway to T-cell exhaustion: an update on implications for chronic infections and tumor evasion. Cancer Immunol Immunother. 2007; 56(5): 739-45. PubMed Abstract | Publisher Full Text

36. F Strong MJ, Laskow $\mathrm{T}$, Nakhoul $\mathrm{H}$, et al.: Latent Expression of the EpsteinBarr Virus (EBV)-Encoded Major Histocompatibility Complex Class ITAP Inhibitor, BNLF2a, in EBV-Positive Gastric Carcinomas. J Virol. 2015; 89(19): 10110-4

PubMed Abstract | Publisher Full Text | Free Full Text | F1000 Recommendation

37. F Camargo MC, Kim W, Chiaravalli AM, et al.: Improved survival of gastric cancer with tumour Epstein-Barr virus positivity: an international pooled analysis. Gut. 2014; 63(2): 236-43.

PubMed Abstract | Publisher Full Text | Free Full Text | F1000 Recommendation

38. Marquitz AR, Mathur A, Shair KH, et al.: Infection of Epstein-Barr virus in a gastric carcinoma cell line induces anchorage independence and global changes in gene expression. Proc Natl Acad Sci U S A. 2012; 109(24): 9593-8. PubMed Abstract | Publisher Full Text | Free Full Text

39. Raab-Traub N, Dambaugh T, Kieff E: DNA of Epstein-Barr virus VIII: B95-8, the previous prototype, is an unusual deletion derivative. Cell. 1980; 22(1 Pt 1): 257-67.

PubMed Abstract | Publisher Full Text

40. Edwards RH, Marquitz AR, Raab-Traub N: Epstein-Barr virus BART microRNAs are produced from a large intron prior to splicing. J Virol. 2008; 82(8): 9094-106. PubMed Abstract | Publisher Full Text | Free Full Text

41. $\mathrm{F}$ Kanda $\mathrm{T}$, Furuse $\mathrm{Y}$, Oshitani $\mathrm{H}$, et al:: Highly Efficient CRISPR/Cas9Mediated Cloning and Functional Characterization of Gastric Cancer-Derived 
Epstein-Barr Virus Strains. J Virol. 2016; 90(9): 4383-93.

PubMed Abstract | Publisher Full Text | Free Full Text | F1000 Recommendation

42. $\mathrm{F}$ Tzellos $\mathrm{S}$, Correia $\mathrm{PB}$, Karstegl $\mathrm{CE}$, et al:: A single amino acid in EBNA-2 determines superior $B$ lymphoblastoid cell line growth maintenance by Epstein-Barr virus type 1 EBNA-2. J Virol. 2014; 88(16): 8743-53. PubMed Abstract | Publisher Full Text | Free Full Text | F1000 Recommendation

43. F Palser AL, Grayson NE, White RE, et al:: Genome diversity of Epstein-Barr virus from multiple tumor types and normal infection. $J$ Virol. 2015; 89(10): 5222-37.

PubMed Abstract | Publisher Full Text | Free Full Text | F1000 Recommendation

44. F Tsai MH, Raykova A, Klinke O, et al:: Spontaneous lytic replication and epitheliotropism define an Epstein-Barr virus strain found in carcinomas. Cell Rep. 2013; 5(2): 458-70.

PubMed Abstract | Publisher Full Text | F1000 Recommendation

45. Midgley RS, Bell AI, Yao QY, et al.: HLA-A11-restricted epitope polymorphism among Epstein-Barr virus strains in the highly HLA-A11-positive Chinese population: incidence and immunogenicity of variant epitope sequences. $J$ Virol. 2003; 77(21): 11507-16.

PubMed Abstract | Publisher Full Text | Free Full Text

46. White RE, Ramer PC, Naresh KN, et al: EBNA3B-deficient EBV promotes B cell lymphomagenesis in humanized mice and is found in human tumors. $J$ Clin Invest. 2012; 122(4): 1487-502.

PubMed Abstract | Publisher Full Text | Free Full Text

47. F Coleman CB, Wohlford EM, Smith NA, et al.: Epstein-Barr virus type 2 latently infects $\mathrm{T}$ cells, inducing an atypical activation characterized by expression of lymphotactic cytokines. J Virol. 2015; 89(4): 2301-12.

PubMed Abstract | Publisher Full Text | Free Full Text | F1000 Recommendation

48. Kimura $\mathrm{H}$, Hoshino $\mathrm{Y}$, Kanegane $\mathrm{H}$, et al:: Clinical and virologic characteristics of chronic active Epstein-Barr virus infection. Blood. 2001; 98(2): 280-6. PubMed Abstract | Publisher Full Text

49. Calattini S, Sereti I, Scheinberg $P$, et al.: Detection of EBV genomes in plasmablasts/plasma cells and non-B cells in the blood of most patients with EBV lymphoproliferative disorders by using Immuno-FISH. Blood. 2010 116(22): 4546-59.

PubMed Abstract | Publisher Full Text | Free Full Text

50. Kimura H, Ito $\mathrm{Y}, \mathrm{Kawabe} \mathrm{S}$, et al:: EBV-associated T/NK-cell lymphoproliferative diseases in nonimmunocompromised hosts: prospective analysis of 108 cases. Blood. 2012; 119(3): 673-86.

PubMed Abstract | Publisher Full Text

51. Fox CP, Shannon-Lowe C, Gothard P, et al.: Epstein-Barr virus-associated hemophagocytic lymphohistiocytosis in adults characterized by high viral genome load within circulating natural killer cells. Clin Infect Dis. 2010; 51(1): 66-9.

PubMed Abstract | Publisher Full Text

52. Kimura $\mathrm{H}$, Morishima $\mathrm{T}$, Kanegane $\mathrm{H}$, et al:: Prognostic factors for chronic active Epstein-Barr virus infection. J Infect Dis. 2003; 187(4): 527-33.

PubMed Abstract | Publisher Full Text

53. Cohen JI, Jaffe ES, Dale JK, et al:: Characterization and treatment of chronic active Epstein-Barr virus disease: a 28-year experience in the United States. Blood. 2011; 117(22): 5835-49.

PubMed Abstract | Publisher Full Text | Free Full Text

54. Mosier DE, Gulizia RJ, Baird SM, et al:: Transfer of a functional human immune system to mice with severe combined immunodeficiency. Nature. 1988; 335(6187): 256-9.

PubMed Abstract | Publisher Full Text

55. Fujiwara S, Matsuda G, Imadome K: Humanized mouse models of epstein barr virus infection and associated diseases. Pathogens. 2013; 2(1): 153-76. PubMed Abstract | Publisher Full Text | Free Full Text

56. Fujiwara S, Imadome K, Takei M: Modeling EBV infection and pathogenesis in new-generation humanized mice. Exp Mol Med. 2015; 47(1): e135. PubMed Abstract | Publisher Full Text | Free Full Text

57. Ishikawa F, Yasukawa M, Lyons B, et al.: Development of functional human blood and immune systems in NOD/SCID/IL2 receptor \{gamma\} chain null mice. Blood. 2005; 106(5): 1565-73.

PubMed Abstract | Publisher Full Text | Free Full Text

58. Shultz LD, Saito $Y$, Najima $Y$, et al:: Generation of functional human T-cell subsets with HLA-restricted immune responses in HLA class I expressing NOD/SCID/IL 2 gammanull humanized mice. Proc Natl Acad Sci U S A . 2010; 107(29): 13022-7.

PubMed Abstract | Publisher Full Text | Free Full Text

59. F Chijioke O, Müller A, Feederle R, et al:: Human natural killer cells prevent infectious mononucleosis features by targeting lytic Epstein-Barr virus infection. Cell Rep. 2013; 5(6): 1489-98.

PubMed Abstract | Publisher Full Text | Free Full Text | F1000 Recommendation
60. F Melkus MW, Estes JD, Padgett-Thomas A, et al.: Humanized mice mount specific adaptive and innate immune responses to EBV and TSST-1. Nat Med. 2006; 12(11): 1316-22.

PubMed Abstract | Publisher Full Text | F1000 Recommendation

61. Yajima M, Imadome K, Nakagawa A, et al:: A new humanized mouse model of Epstein-Barr virus infection that reproduces persistent infection, lymphoproliferative disorder, and cell-mediated and humoral immune responses. J Infect Dis. 2008; 198(5): 673-82. PubMed Abstract | Publisher Full Text

62. Sato K, Misawa N, Nie C, et al:: A novel animal model of Epstein-Barr virusassociated hemophagocytic lymphohistiocytosis in humanized mice. Blood. 2011; 117(21): 5663-73.

PubMed Abstract | Publisher Full Text

63. Toussirot E, Roudier J: Pathophysiological links between rheumatoid arthritis and the Epstein-Barr virus: an update. Joint Bone Spine. 2007; 74(5): 418-26. PubMed Abstract | Publisher Full Text

64. F Erre GL, Mameli G, Cossu D, et al:: Increased Epstein-Barr Virus DNA Load and Antibodies Against EBNA1 and EA in Sardinian Patients with Rheumatoid Arthritis. Viral Immunol. 2015; 28(7): 385-90. PubMed Abstract | Publisher Full Text | F1000 Recommendation

65. F Mahabadi M, Faghihiloo E, Alishiri GH, et al.: Detection of Epstein-Barr virus in synovial fluid of rheumatoid arthritis patients. Electron Physician. 2016; 8(3): 2181-6.

PubMed Abstract | Publisher Full Text | Free Full Text | F1000 Recommendation

66. Kuwana $\mathrm{Y}$, Takei M, Yajima M, et al.: Epstein-Barr virus induces erosive arthritis in humanized mice. PLoS One. 2011; 6(10): e26630. PubMed Abstract | Publisher Full Text | Free Full Text

67. F Ma SD, Xu X, Jones R, et al:: PD-1/CTLA-4 Blockade Inhibits Epstein-Barr Virus-Induced Lymphoma Growth in a Cord Blood Humanized-Mouse Model. PLoS Pathog. 2016; 12(5): e1005642.

PubMed Abstract | Publisher Full Text | Free Full Text | F1000 Recommendation

68. F Landtwing V, Raykova A, Pezzino G, et al:: Cognate HLA absence in trans diminishes human NK cell education. J Clin Invest. 2016; 126(10): 3772-82. PubMed Abstract | Publisher Full Text | Free Full Text | F1000 Recommendation

69. $\mathrm{F}$ Lin $\mathrm{X}$, Tsai MH, Shumilov A, et al:: The Epstein-Barr Virus BART miRNA Cluster of the M81 Strain Modulates Multiple Functions in Primary B Cells. PLoS Pathog. 2015; 11(12): e1005344.

PubMed Abstract | Publisher Full Text | Free Full Text | F1000 Recommendation

70. F Whitehurst CB, Li G, Montgomery SA, et al.: Knockout of Epstein-Barr virus BPLF1 retards B-cell transformation and lymphoma formation in humanized mice. mBio. 2015; 6(5): e01574-15.

PubMed Abstract | Publisher Full Text | Free Full Text | F1000 Recommendation

71. F Lee EK, Joo EH, Song K, et al.: Effects of lymphocyte profile on development of EBV-induced lymphoma subtypes in humanized mice. Proc Natl Acad Sci U S A. 2015; 112(42): 13081-6.

PubMed Abstract | Publisher Full Text | Free Full Text | F1000 Recommendation

72. F Gregorovic G, Boulden EA, Bosshard R, et al.: Epstein-Barr Viruses (EBVs) Deficient in EBV-Encoded RNAs Have Higher Levels of Latent Membrane Protein 2 RNA Expression in Lymphoblastoid Cell Lines and Efficiently Establish Persistent Infections in Humanized Mice. J Virol. 2015; 89(22): 11711-4.

PubMed Abstract | Publisher Full Text | Free Full Text | F1000 Recommendation

73. F Chijioke O, Marcenaro E, Moretta A, et al.: Role of the 2B4 Receptor in CD8 T-Cell-Dependent Immune Control of Epstein-Barr Virus Infection in Mice With Reconstituted Human Immune System Components. J Infect Dis. 2015; 212(5): 803-7.

PubMed Abstract | Publisher Full Text | F1000 Recommendation

74. F Ma SD, Xu X, Plowshay J, et al.: LMP1-deficient Epstein-Barr virus mutant requires T cells for lymphomagenesis. J Clin Invest. 2015; 125(1): 304-15. PubMed Abstract | Publisher Full Text | Free Full Text | F1000 Recommendation

75. F Antsiferova O, Muller A, Ramer PC, et al.: Adoptive transfer of EBV specific CD8 ${ }^{+} \mathrm{T}$ cell clones can transiently control EBV infection in humanized mice. PLOS Pathog. 2014; 10(8): e1004333.

PubMed Abstract | Publisher Full Text | Free Full Text | F1000 Recommendation

76. F Xiang Z, Liu Y, Zheng J, et al:: Targeted activation of human $\mathbf{V} \gamma \mathbf{9 V} \mathbf{\delta}$ 2-T cells controls epstein-barr virus-induced $B$ cell lymphoproliferative disease. Cancer Cell. 2014; 26(4): 565-76.

PubMed Abstract | Publisher Full Text | F1000 Recommendation

77. F Heuts F, Rottenberg ME, Salamon D, et al:: T cells modulate Epstein-Barr virus latency phenotypes during infection of humanized mice. $J$ Virol. 2014; 88(6): 3235-45.

PubMed Abstract | Publisher Full Text | Free Full Text | F1000 Recommendation 


\section{Open Peer Review}

\section{Current Peer Review Status:}

\section{Editorial Note on the Review Process}

Faculty Reviews are review articles written by the prestigious Members of Faculty Opinions. The articles are commissioned and peer reviewed before publication to ensure that the final, published version is comprehensive and accessible. The reviewers who approved the final version are listed with their names and affiliations.

\section{The reviewers who approved this article are:}

\section{Version 1}

\section{Bo Zhao}

Brigham and Women's Hospital, Harvard Medical School, Boston, USA

Competing Interests: No competing interests were disclosed.

\section{Richard M. Longnecker}

Northwestern University, Chicago, Chicago, IL, USA

Competing Interests: No competing interests were disclosed.

\section{Alan K Chiang}

Department of Paediatrics and Adolescent Medicine, The University of Hong Kong, Hong Kong, Hong Kong Competing Interests: No competing interests were disclosed.

\section{Christian Münz}

Department of Viral Immunology, Institute of Experimental Immunology, University of Zürich, Zurich, Switzerland

Competing Interests: No competing interests were disclosed. 
The benefits of publishing with F1000Research:

- Your article is published within days, with no editorial bias

- You can publish traditional articles, null/negative results, case reports, data notes and more

- The peer review process is transparent and collaborative

- Your article is indexed in PubMed after passing peer review

- Dedicated customer support at every stage

For pre-submission enquiries, contact research@f1000.com 